\title{
Host specificity of the tribe Chrysidini (Hymenoptera: Chrysididae) in Estonia ascertained with trap-nesting
}

\author{
MAdLI PÄRN ${ }^{1}$, VILLu SOON ${ }^{1,2, *}$, TuUli VALLISOO ${ }^{1}$, KRISTIINA HOVI ${ }^{1}$ and JAAN LUIG ${ }^{2}$ \\ ${ }^{1}$ Department of Zoology, Institute of Ecology and Earth Sciences, University of Tartu, Vanemuise 46, Tartu 51014, Estonia; \\ e-mails: villu.soon@ut.ee; a71910@ut.ee; tuuli.vallisoo@gmail.com; kristiina.hovi@gmail.com \\ ${ }^{2}$ Zoological Museum, Natural History Museum, University of Tartu, Vanemuise 46, 51014 Tartu, Estonia; \\ e-mail: jaan.luig@gmail.com
}

Key words. Hymenoptera, Chrysididae, cuckoo wasps, parasite specialization, trap nest, Chrysis, host specificity

\begin{abstract}
Cuckoo wasps (Chrysididae) are a medium-sized and widespread family of Hymenoptera whose species are generally parasitoids or cleptoparasites of solitary wasps and bees. The identities of the hosts are known from various studies and occasional records; however the utility of such data is often low due to unstable taxonomy of the species and the inappropriate methods used to determine the host species. Therefore, despite numerous publications on the subject, the host-parasite relationships of cuckoo wasps are poorly understood. Moreover, a revision of existing literature reveals that cuckoo wasps are often unreasonably considered to be unspecialized (i.e., sharing host species). In this study we use an accurate method (trap-nests) to determine the host relationships of Estonian cuckoo wasps of the genera Chrysis and Trichrysis and determine their level of specialization. 568 trap nest bundles (each containing 15-20 single reed stems) were established at 361 locations across Estonia during the vegetation periods of 2009-2011. Nests built in traps were opened and the order of cells documented in order to determine the host-parasite relationships of mason wasps and cuckoo wasps. Altogether, 5386 insects were recorded, including 12 species of Chrysidini. Hosts of all 12 cuckoo wasp species were determined and included some not previously recorded. Analysis of host-parasite relationships revealed that Estonian species of Chrysidini exhibit a greater degree of host specialization than previously thought, with only a minimal overlap in hosts between species. Such a high degree of specialization accounts for the high species diversity of cuckoo wasps, as the diversity of parasitic insects is often associated with narrow host specialization.
\end{abstract}

\section{INTRODUCTION}

Cuckoo wasps, also known as gold wasps, are a colourful family belonging to the order Hymenoptera. There are more than 3000 species in four subfamilies, of which only two, Cleptinae and Chrysidinae, occur in Europe (Kimsey \& Bohart, 1991).

All cuckoo wasps are parasitoids or cleptoparasites whose hosts are mainly solitary hymenopterans. Species of the subfamily Cleptinae are parasites of sawflies (Tenthredinoidea), while species belonging to Chrysidinae mostly parasitize other solitary wasps and bees (Crabronidae, Megachilidae, Sphecidae, Vespidae) (Kimsey \& Bohart, 1991). Chrysis, which belongs to the subfamily Chrysidinae, is the most diverse cuckoo wasp genus in northern Europe and the C. ignita species group includes most of the diversity. Revisions of the European species of this genus have led to the discovery of considerable diversity within this group, though identification of the species based on external features remains difficult (Linsenmaier, 1959; Soon \& Saarma, 2011; Soon et al., 2014).

There is a fair amount of literature on the host species of cuckoo wasps, which generally indicates that mason wasps (Vespidae: Eumeninae) are the main hosts of Northern European species of Chrysis (e.g. Berland \& Bernard, 1938; Morgan, 1984). Different species of Chrysis are known to exhibit different levels of host specialization. While some species are known to parasitize one species of host, others parasitize several species, from different families that differ in their ecology. According to Kimsey \& Bohart (1991), the ecology of the species of Chrysis is very similar, exhibiting relatively low host specificity and specializing mainly on a particular nest type or host genus. If this is the case, the high diversity present in the group is surprising, since the species diversity of parasitic insects is generally believed to result from high host specificity (Ebeling et al., 2012). Conclusions about the low host specificity of many cuckoo wasps are based on data available in the literature, the reliability of which is rarely questioned. A critical evaluation of published records, however, is required if one is to avoid records that use inappropriate taxonomy or methods of collecting data. This is most evident in the case of older publications, with numerous records published more than 100 years ago. The taxonomy of this family and methods of study have improved considerably since then. For example, the definition of Chrysis ignita has changed considerably and field observations of wasps occurring in the same area are no longer considered to be proof of a host-parasite relationship. Despite this, old records of host-parasite relationships are often reduplicated in modern monographic studies.

\footnotetext{
* Corresponding author.
} 
Problems related to taxonomy and nomenclature may generate misleading results when analysing host specificity. The most diverse and difficult group of cuckoo wasps in northern Europe is the Chrysis ignita species group (Soon et al., 2014), which has been differently treated by various authors (e.g. Kunz, 1994; Linsenmaier, 1997; Smissen, 2010). C. ignita was among the first cuckoo wasps described by Linnaeus (1758) and since then numerous new species have been separated from it, but these species are not generally widely accepted. While the taxonomy of a few northern European species in this species group is relatively stable (i.e. Chrysis fulgida and C. iris), due to their distinctive colouration, treatment of most others has been unstable. The differing treatment of the species in the $C$. ignita group reflects the lack of distinct morphological features within this group. Moreover, there are cryptic species in this group (Soon \& Saarma, 2011; Soon et al., 2014). Thus, the taxon identities of the more problematic groups in the literature need to be treated with care (Schmid-Egger et al., 1995).

Another likely reason for incorrect conclusions about host-parasite relationships is the use of unsuitable methods for collecting data. Research into the host-parasite relationships of cuckoo wasps has seldom been the main topic of studies; rather, such data often represent a secondary outcome or result from unplanned observations. Therefore, the suitability of the research methods for addressing hostparasite relationships has not generally been a primary concern. Much of the published evidence on cuckoo wasp host specificity comes from observations on a particular species near the nest of a potential host (e.g. Smith, 1858; Ashmead, 1894; Balthasar, 1943; Asís et al., 1991). Although some studies include more detailed descriptions of cuckoo wasp behaviour near the nest of a potential host, describing excavation and/or entrance into nests, all such cases are only observations on a potential host not evidence of parasitization. Another frequently used indirect method for revealing the host-parasite relationships of cuckoo wasps is based on the occurrence of potential hosts within a given area (e.g. Heinrich, 1964; Gayubo et al., 1987). While this method is useful for identifying potential hosts it again is not evidence of a host-parasite relationship.

Furthermore, numerous publications list hosts but do not cite the source of the data or present an adequate description of the methods (e.g. Balthasar, 1942; Doronin, 1996; Schneider, 1997; Smissen, 2001). Therefore, it is not possible to determine the reliability of the host-parasite relationships presented in such publications.

In addition, host specialization is not static and may change over time (Habermannová et al., 2013). Therefore, host-parasite relationships determined 100 years ago describe the insect communities at that time, which may differ from the present situation.

Thus, a truly reliable host relationship depends on recording a cuckoo wasp hatching from a host nest the identity of which is well established. Only a few of the published host-parasite relationships of cuckoo wasps are based on the rearing of these wasps from the nests of hosts, since nests are not easy to find or transfer to a laboratory for breeding (Enslin, 1933; Tormos et al., 2009).

The introduction of the trap-nest method has improved the situation significantly. Many solitary wasps and bees build their nests in cavities including abandoned burrows in wood or hollow plant stems. Such wasps and bees also adopt artificial cavities such as reed or bamboo straws (Budrienè et al., 2004; Budrys et al., 2010; Matsumoto \& Makino, 2011), or blocks of wood with holes of different diameter drilled into them (Krombein, 1967; Alves-dosSantos, 2003; Matsumoto \& Makino, 2011).

Trap-nests have mainly been used to determine the species composition of communities in various ecological studies (Tscharntke et al., 1998; Gathmann \& Tscharntke, 1999; Klein et al., 2002; Matsumoto \& Makino, 2011). As with the approaches described above, these studies have generally provided data on the host-parasite relationships of cuckoo wasps as a side product. Hence, some of the methods used could have provided misleading data. For example, nest usurpation is a common phenomenon (Benno, 1950; Krombein, 1967; Schneider, 1991; Černá et al., 2013) in which two or more potential species of hosts inhabit the same nest cavity. Usually this is not taken into consideration as all species emerging from the same trap cavity are expected to be inhabitants of the same nest. To determine the hosts of cuckoo wasps with certainty, it is important to open trap-nests, determine the order of the cells in it and rear the contents of each cell separately (Cooper, 1953; Medler, 1964; Krombein, 1967; Boesi et al., 2005). In this way it is possible to detect nest usurpation and take it into consideration in order to avoid incorrect conclusions concerning host specificity.

\section{HYPOTHESES}

Due to the lack of uniformity in the taxonomic treatments and methods used to determine host species, we consider the conclusion that Chrysis exhibits relatively low host specificity to be unreliable. Moreover, high host specificity, which is currently believed to exist, could account for the high diversity of cuckoo wasps in this genus. The main objective of this study is to evaluate the host specificity of cuckoo wasps by using trap-nests. We aim to test the following hypotheses:

1. Cuckoo wasps have narrower host ranges than currently believed.

2. There is no overlap in the host species of different species of cuckoo wasp.

3. Cuckoo wasp species prefer a specific host even when other potential hosts are present.

\section{MATERIAL AND METHODS}

This study is based on material collected from trap-nests that were placed at 361 locations across Estonia (Fig. 1) over three consecutive years from 2009 until 2011. Trap-nests were made of stems of common reed (Phragmites australis) tied together in bundles of 15-20 with tape, with each bundle containing straws of different diameters. Altogether, 568 bundles were prepared, and 1-10 were placed at each location in June. Trap-nests were attached to various substrates at heights ranging from one to two 


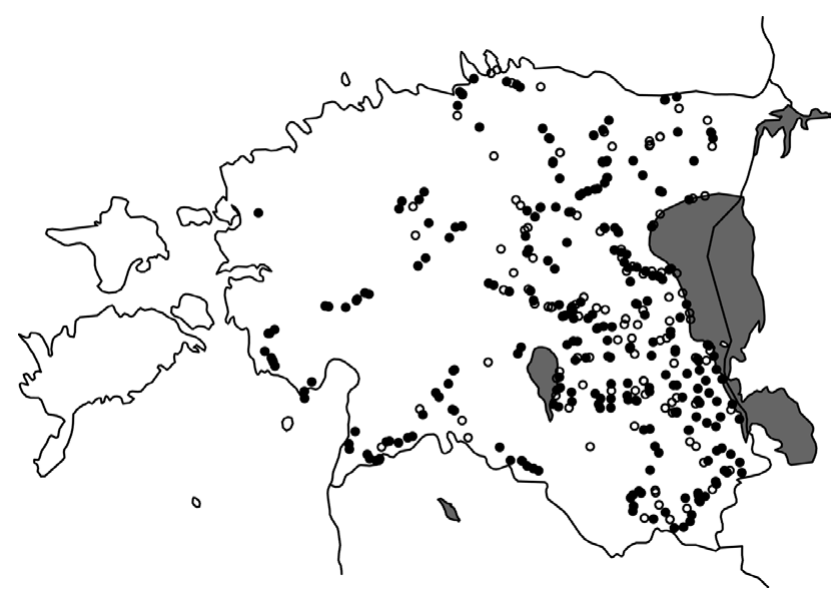

Fig. 1. Map showing the locations of the trap-nests in Estonia. Solid circles indicate localities where potential hosts of cuckoo wasps were trapped and empty circles localities where no potential hosts were trapped.

meters above the ground. When selecting places for the traps we preferred substrates where cavity nesting wasps and bees nested, which increased the likelihood of the trap-nests being found. Commonly used substrates were walls of traditional buildings made of wood or clay and dead tree trunks. In October all the nests were collected, numbered and placed in cardboard boxes for storage at outside temperatures to ensure the normal induction of diapause.

At the end of December the trap-nests were brought into the laboratory for rearing. Straws were cut open and all larvae put into separate plastic containers, each labelled with a unique code indicating the order in which they were present in each straw, the trap-nest, the location and the year of collecting. When numbering cells we started from the innermost, the oldest. All larvae were kept at room temperature until they emerged as adults. Adults were then placed either in a freezer or ethanol $(96 \%)$ to kill and preserve them.

The host relationship of each cuckoo wasp was rated as certain, dubious or undetermined depending on its position in a straw. All occasions when the cell with a cuckoo wasp was surrounded by those of the same host species, i.e. the same host species hatched from either side, were considered certain. As an exception, occasions when two cuckoo wasps of the same species hatched from cells surrounding the cell(s) of one host species were also considered certain. All instances when the cuckoo wasp hatched from an outermost or innermost cell, or one of the hosts in cells adjacent to the cuckoo wasp failed to hatch, were considered as dubious, due to our inability to exclude the possibility of nest sharing by more than one potential host species. The host was considered undetermined when the cuckoo wasp was surrounded by different potential host species, hosts that failed to hatch or all cells were infested with cuckoo wasps.

In order to determine whether or not cuckoo wasps selected host species depending on host species availability at a given locality or preferred certain hosts irrespective of abundance, generalized linear mixed models (SAS 9.2, GLIMMIX procedure, SAS Institute Inc.) were used. Although we could detect potential availability of hosts in space we could not detect it over time. Nevertheless, we assume that availability of hosts over time was more or less constant since the flight periods of the cuckoo wasps and their hosts overlapped during the short Estonian summer. All cases of evidence of more than one potential species of host for a species of Chrysis were included in this analysis. Only loca- tions at which the host species were identified on at least one occasion were included in the analysis. All specimens of the host species were regarded as separate observations whether they were parasitized or not. All analyses were carried out for every Chrysis species separately, in which the binary dependent variable was the degree of parasitisation ( 1 or 0 ), and the independent variables the identity of the host, the ratio of the abundance of host to that of all hosts at a location (available for all but one species) and the location itself a random variable. An effect of the host species on the dependent variable was interpreted as evidence of a cuckoo wasp host preference, while an effect of the frequency of potential alternative hosts could be interpreted as host-switching and therefore the existence of a hierarchy of host-preference. In other words, if high abundance of host species A reduces the probability of species B being parasitized, then it is possible that host B is lower in the host preference hierarchy than host A with host B only parasitized when host $\mathrm{A}$ is rare.

\section{RESULTS}

Three hundred and sixty one of the 568 trap-nest were used by wasps and bees, which produced 6023 nest cells of which $5386(89.4 \%)$ produced insects, which are now in the collection of the Zoological Museum, Natural History Museum of University of Tartu. All of the potential host species (i.e. excluding parasites such as: Ichneumonidae, Braconidae, Eulophidae, Pteromalidae and Gasteruptiidae) are listed in Table 1, along with the numbers of specimens and all of the possible host relationships. The most numerous of them were mason wasps (Eumeninae), crabronid wasps (Crabronidae), leafcutter bees (Megachilidae) and plasterer bees (Colletidae). There were 19 species belonging to five genera of the mason wasp subfamily: Ancistrocerus, Symmorphus, Discoelius, Euodynerus and Gymnomerus, and 14 species belonging to 7 genera of Crabronid wasps with Trypoxylon being the most abundant. Cuckoo wasps were represented by only two genera - Chrysis and Trichrysis. There were 438 specimens of 11 different species of the genus Chrysis, with Chrysis solida, $C$. angustula, $C$. corusca, and $C$. fulgida the most abundant. At least one individual of each cuckoo wasp species hatched from a cell adjacent to a potential host enabling the determination of the host. All hosts of the genus Chrysis belonged to the following genera: Ancistrocerus, Symmorphus, Discoelius and Euodynerus. Most of the species of cuckoo wasps parasitized only one host species, but species with a wider host range were also present e.g. C. angustula, C. fulgida, C. iris, C. solida and Trichrysis cyanea. Nest sharing by potential hosts was recorded in 42 straws from which two potential host species emerged (details not presented).

Below we list the results of our study of each of the cuckoo wasp species caught, including their host-parasite relationships. The total number of instances of a species of cuckoo wasp being reared from the nest of a host is given along with the level of confidence (certain/dubious) based on the position of the parasitized cell relative to host cells. In addition, the number of occasions on which the host species was not determined is also given. The results of the statistical analyses of the host preferences of $C$. angustula, 
TABLE 1. List of the potential hosts reared from trap-nests and their documented relationships with cuckoo wasps. Numbers of specimens of the genus Hylaeus are only those recorded in 2010. Primary host species are marked with a plus (+), less preferred host species or less reliably documented relationships are marked with an asterisk $(*)$.

Potential host species

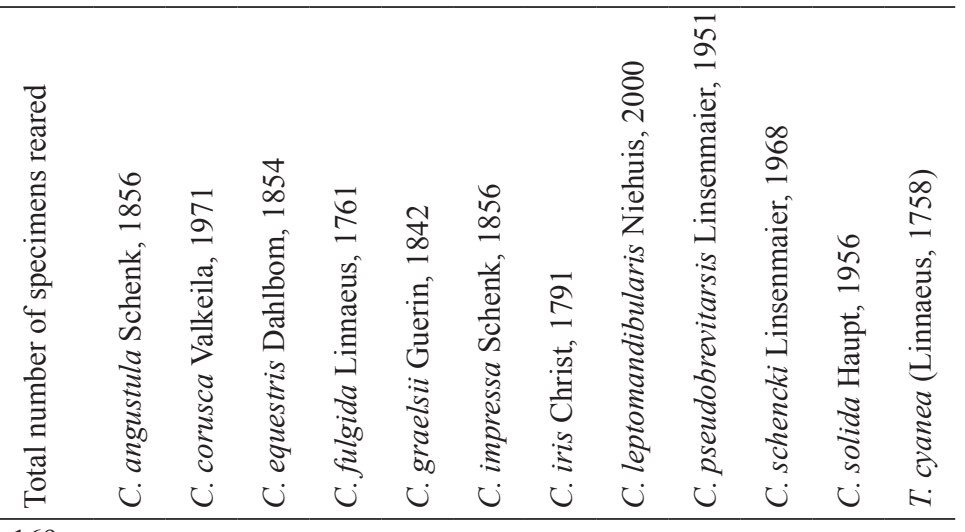

Ancistrocerus antilope (Panzer, 1798)

A. claripennis Thomson, 1874

A. ichneumonideus (Ratzeburg, 1844)

A. parietinus (Linnaeus, 1761)

A. parietum (Linnaeus, 1758)

A. trifasciatus (Müller, 1776)

Symmoprhus allobrogus (Saussure, 1855)

S. angustatus (Zetterstedt, 1838)

S. bifasciatus (Linnaeus, 1761)

S. connexus (Curtis, 1826)

S. crassicornis (Panzer, 1798)

S. debilitatus (Saussure, 1856)

S. gracilis (Brulle, 1832)

S. murarius (Linnaeus, 1758)

Discoelius dufourii Lepeletier, 1841

D. zonalis (Panzer, 1801)

Euodynerus notatus (Jurine, 1807)

E. quadrifasciatus (Fabricius, 1793)

Gymnomerus laevipes (Shuckard, 1837)

Crossocerus subulatus (Dahlbom, 1845)

69

18

3

89

37

1219

186

3

552

13

50

149

125

14

1

239

223

10

4

3

Nitela borealis Valkeila, 1974

Passaloecus corniger Shuckard, 1837

P. insignis (Vander Linden, 1829)

P. singularis Dahlbom, 1844

P. turionum Dahlbom, 1844

Pemphredon mortifer Valkeila, 1972

Psenulus brevitarsis Merisuo, 1937

P. concolor (Dahlbom, 1843)

P. pallipes (Panzer, 1798)

Rhopalum clavipes (Linnaeus, 1758)

T. minus Beaumont, 1945

Agenioideus cinctellus (Spinola, 1808)

Anoplius caviventris (Aurivillius, 1907)

Auplopus carbonarius (Scopoli, 1763) 28

Dipogon bifasciatus (Geoffroy, 1785) 37

D. subintermedius (Magretti, 1886) 50

Anthophora furcata (Panzer, 1798) 3

Chelostoma rapunculi (Lepeletier, 1841) 11

Heriades truncorum (Linnaeus, 1758) 52

Hylaeus cardioscapus Cockerell, 1924

H. communis Nylander, $1852 \quad 256$

H. difformis (Eversmann, 1852) 28

Megachile centuncularis (Linnaeus, 1758) 36

M. lapponica Thomson, $1872 \quad 31$

M. ligniseca (Kirby, 1802) 23

Osmia caerulescens (Linnaeus, 1758) 40

O. bicornis (Linnaeus, 1758) 
TABLE 2. Host preferences of Chrysis angustula $(\mathrm{N}=621), C$. fulgida $(\mathrm{N}=140)$ and $C$. solida $(\mathrm{N}=386)$ determined using a test of type III fixed effects. The effects of host species and relative abundance of potential hosts on the degree of parasitization (dependent variable) were tested using linear mixed models, num DF $=$ degrees of freedom numerator, den $\mathrm{DF}=$ degrees of freedom denominator, $\operatorname{Pr}>\mathrm{F}=$ significance level.

\begin{tabular}{lcccc}
\hline Effect & num DF & den DF & F value & $\operatorname{Pr}>$ F \\
\hline Chrysis angustula & & & & \\
$\quad$ Host species & 3 & 614 & 9.44 & $<0.001$ \\
$\quad$ Symmorphus allobrogus & 1 & 17.49 & 1.00 & 0.33 \\
$\quad$ S. bifasciatus & 1 & 15.86 & 0.10 & 0.75 \\
$\quad$ S. debilitatus & 1 & 54.21 & 0.02 & 0.89 \\
Chrysis fulgida & & & & \\
$\quad$ Host species & 1 & 137 & 4.69 & 0.032 \\
$\quad$ Symmorphus bifasciatus & 1 & 137 & 0.06 & 0.81 \\
Chrysis solida & & & & \\
$\quad$ Host species & 1 & 383 & 0.79 & 0.37 \\
$\quad$ Ancistrocerus trifasciatus & 1 & 35.1 & 2.46 & 0.13 \\
\hline
\end{tabular}

C. fulgida and C. solida are presented in Table 2 and explained below in the respective species sections.

\section{Chrysis angustula Schenck, 1856}

Total: 111 specimens.

Ancistrocerus trifasciatus: 4 dubious.

Symmorphus allobrogus: 2 certain.

S. bifasciatus: 23 certain, 41 dubious.

S. debilitatus: 1 dubious.

Host undetermined: 40.

Chrysis angustula showed host preference ( $\mathrm{p}<0.001$; Table 2), but as the relative abundances of alternative hosts did not have significant effects, there was no evidence of host-switching. Since there were more than two host species, a Tukey-Kramer method was used to make pairwise comparisons: this indicated a preference for Symmorphus bifasciatus over $S$. allobrogus $(\mathrm{p}=0.012)$ and Ancistrocerus trifasciatus $(\mathrm{p}<0.001)$.

\section{C. corusca Valkeila, 1971}

Total: 71 specimens.

Symmorphus gracilis: 9 certain, 12 dubious.

Host undetermined: 50.

\section{C. equestris Dahlbom, 1854}

Total: 19 specimens.

Discoelius zonalis: 11 certain, 8 dubious.

\section{C. fulgida Linnaeus, 1761}

Total: 66 specimens

Symmorphus bifasciatus: 7 certain, 4 dubious.

S. crassicornis: 3 certain, 13 dubious.

S. murarius: 2 dubious.

Host undetermined: 37.

Symmorphus crassicornis was preferred over S. bifasciatus (Table 2). Symmorphus murarius was omitted from the analysis because too few (14) individuals were reared during this study. Also the variable "location" was included as a fixed effect due to the low number of locations. Although the results showed a preference for one host over the other $(\mathrm{p}=0.032)$, host abundance itself was not significant and therefore there was no evidence of host-switching.

\section{C. graelsii Guérin, 1842}

Total: 4 specimens.

Euodynerus notatus: 2 certain, 2 dubious.

\section{C. impressa Schenck, 1856}

Total: 12 specimens

Ancistrocerus claripennis: 3 dubious.

A. parietinus: 3 dubious.

A. trifasciatus: 1 dubious.

Host undetermined: 5 .

\section{C. iris Christ, 1791}

Total: 28 specimens.

Symmorphus allobrogus: 1 certain, 12 dubious.

S. bifasciatus: 1 dubious.

S. crassicornis: 1 dubious.

Host undetermined 13.

\section{C. leptomandibularis Niehuis, 2000}

Total: 1 specimen.

Symmorphus debilitatus: 1 dubious.

\section{C. pseudobrevitarsis Linsenmaier, 1951}

Total: 3 specimens.

Euodynerus notatus: 2 certain, 1 dubious.

\section{C. schencki Linsenmaier, 1968}

Total: 2 specimens.

From Ancistrocerus trifasciatus: 2 dubious.

\section{C. solida Haupt, 1957}

Total: 120 specimens.

Ancistrocerus trifasciatus: 26 certain, 33 dubious.

Euodynerus notatus: 1 certain.

Symmorphus debilitatus: 2 dubious.

Host undetermined: 58 .

There was no preference for either of the two host species, Euodynerus notatus and Ancistrocerus trifasciatus (p $=0.37$ ), and the relative abundances of the host species also had no significant effects, indicating no host preference or host-switching (Table 2). Symmorphus debilitatus was not included in the analysis, because this species was only recorded as a host of $C$. solida in a single nest, from which the cuckoo wasp emerged from the outermost cell. Despite the low power of this analysis A. trifasciatus is considered to be the main host of Chrysis solida in Estonia because of the numerous records of it being reared in association with this species.

\section{Trichrysis cyanea (Linnaeus, 1758)}

Total: 41 specimens.

Anoplius caviventris: 1 dubious.

Auplopus carbonarius: 1 certain, 2 dubious.

Dipogin bifasciatus: 1 dubious.

Trypoxylon figulus: 6 certain, 19 dubious.

Trypoxylon minus: 2 dubious.

Host undetermined: 11. 


\section{DISCUSSION}

Eleven of the 25 Estonian species of Chrysis and a single representative of the genus Trichrysis were collected using trap-nests. As some Estonian species of Chrysis parasitize ground-nesting host species, the eleven species make up most of the species that parasitize cavity-nesting wasps. All of these species exhibited some degree of specialization to a particular host species.

While all species of cuckoo wasps were associated with at least one host species the overall efficiency of detecting host species with the method used was rather low. For 478 of the cuckoo wasps that emerged the host could not be determined for nearly half of them. The main reason for this was that all the cells of a nest were parasitized and therefore no host emerged. Although this problem was detected during the first year (2009) of field-work and breeding in laboratory we could not prevent it. The risk of all nest cells being parasitized can be slightly reduced by providing longer nesting cavities. With more cells in one nest the chances of at least some host specimens escaping parasitism within the same nest is higher, which enables the founder of the nest to be determined.

Only single species of hosts were recorded for Chrysis equestris and C. corusca. Nineteen individuals of $C$. equestris were reared from trap-nests (all in 2011) and 11 of them parasitized Discoelius zonalis. This mason wasp species is recorded in the literature as a host of $C$. equestris, although with little supporting evidence (Wiesner, 2006). Literature on the host relationships of $C$. corusca is practically nonexistent, because it has only been regarded as a distinct species for about 15 years. The only trustworthy claim comes from the work of Steffan-Dewenter \& Leschke (2003), which mentions the host is a species of mason wasp. In the current study Symmorphus gracilis was determined as the host species on 9 occasions and 12 C. corusca were reared from an outermost cell of the same host's nest. The reason for our inability to determine the host of 50 specimens is that on most occasions $C$. corusca parasitized all the brood cells within a nest. This is likely the result of the cuckoo wasp habit of continuously inspecting the nest of a host and laying eggs whenever nest development is at an appropriate stage (Linsenmaier, 1997).

Some of the species of cuckoo wasps were relatively rare in the trap-nests and therefore, despite being able to determine their host(s), the data remained too limited to allow statistical analysis. These species were: C. graelsii, C. leptomandibularis, C. pseudobrevitarsis and C. schencki. Only single specimens of C. graelsii and C. pseudobrevitarsis were reared from the middle cells of the nests of their host, which was Euodynerus notatus on both occasions. This species has been previously mentioned as a host of both these species of cuckoo wasps (Herrmann, 1996; Saure, 1998). None of these cuckoo wasp species are rare in Estonia, and their rarity in mason wasp nests in trapnests is surprising.

Six species of the cuckoo wasps collected apparently parasitized several hosts: Chrysis angustula, C. fulgida, C. impressa, C. iris, C. solida and Trichrysis cyanea, all of which parasitized at least two host species. Unfortunately, on all four occasions, specimens of $C$. impressa hatched from an outermost cell of a host nest, so host nest sharing cannot be excluded. However, since Ancistrocerus parietinus was the host in two of these cases, it increases the likelihood that it is a host. Moreover, this mason wasp is also listed as a host of $C$. impressa in the literature (Morgan, 1984). Although Ancistrocerus trifasciatus was also determined as a host (although only based on emergence from one outermost cell and thus uncertain), we consider it unlikely that it is an important host of this cuckoo wasp. The potter wasp was very abundant in trap nests, but only once recorded in close proximity to C. impressa, which is also rather common, and even then as an unconfirmed host.

Although many $C$. iris were reared from the trap-nests, we collected insufficient reliable data for a statistical analysis of its host-parasite relationships. Symmorhpus allobrogus was the only definite host of $C$. iris, and the single instances of emergence from the nests of $S$. bifasciatus and S. crassicornis remain dubious, as the parasite emerged from the outermost cell on both occasions. S. allobrogus has not been recorded as a host of this cuckoo wasp before, but both $S$. crassicornis and S.murarius are recorded as hosts in earlier literature (Abeille de Perrein, 1879; du Buysson, 1891-1896; Alfken, 1915). It is possible that $S$. allobrogus is the preferred host of $C$. iris in Estonia, while other hosts are used in Western Europe.

Chrysis angustula, $C$. fulgida and $C$. solida were abundant and all had more than one potential host. Therefore, we ran a statistical analysis to determine whether one host species was preferred over another. All potential hosts were included in the analysis for $C$. angustula, although it was apparent that the data on $S$. debilitatus and $S$. allobrogus were limited. As expected, the results demonstrated two significant relationships: $S$. bifasciatus was preferred over both $S$. allobrogus and Ancistrocerus trifasciatus, which means that $S$. bifasciatus was the preferred host species. It was not possible to compare $S$. bifasciatus and $S$. debilitatus due to insufficient data for $S$. debilitatus. There was also no evidence of host-switching, since the percentage parasitism of a host species was not significantly dependent on the abundance of the other potential hosts.

With five different host species Trichrysis cyanea was the least specialized cuckoo wasp, but there was insufficient data for a statistical analysis of its preferences. This cuckoo wasp is known to be a generalist parasitizing nests of various cavity nesting wasps and bees (Tormos et al., 1996; Gathmann \& Tcharntke, 1999). Nevertheless, most of its host species were not detected with certainty in this study and it appears that Trypoxylon figulus is the main host of this species in Estonia. Curiously all the host species store spiders for their offspring, which indicates that this species might be a specialist of a particular type of food provision rather than of a particular host. Nevertheless this is unlikely since $T$. cyanea is reported as parasite of various wasps storing a different type of food, i.e. Pemphredon lethifer and Psenulus pallipes, which store aphids (Tormos et al., 1996). 
Despite being reared from the nests of Symmorphus bifasciatus on most occasions, statistical analysis indicate that $S$. crassicornis was the preferred host of Chrysis fulgida. Thus, while $C$. fulgida was attracted to the nests of both hosts, the common S. bifasciatus was parasitized only when there were no nests of the preferred host. The ability to parasitize a more abundant host in addition to the preferred host is a good strategy, which enables individuals to survive in less favourable situations, while retaining its own niche as a parasite of the less common species.

Although two different hosts were determined for C. solida it was clearly a specialist on Ancistrocerus trifasciatus, and the single certain record of E. notatus is an infrequent alternative. However, no significant preference was recorded for either host due to limited data, as both species were only present at two locations.

Based on the results, it can be concluded that there is little overlap in the host species of species of the genus Chrysis in Estonia (Table 1). Although both C. angustula and C. fulgida used Symmorphus bifasciatus as a host, it was only the primary host of $C$. angustula and the less preferred host of $C$. fulgida, which was only parasitized when the preferred host was rare. Chrysis graelsii and C. pseudobrevitarsis were exceptional in that both parasitized the same host species, Euodynerus notatus. In this case both cuckoo wasp species are competing for the same resource. Nevertheless this is not contrary to the theory of host specialization as a driver of speciation since these cuckoo wasps are from different species groups and therefore specialization on this host may have evolved independently. Alternatively, one of these cuckoo wasps may have a different species as its primary host, but further data would be needed to determine this.

Reliable data is too limited to determine trends in host selection of cuckoo wasps at a geographic scale. However, differences in host specialization in different areas are likely since the distribution areas of the cuckoo wasps studied reach central Europe and beyond, where more potential host species are available than in northern Europe. Moreover, the abundances of host species differ in areas with different climates, which would affect the availability of the different hosts even when the same host species are present. Generally it appears that cuckoo wasps specialize on parasitizing a single species or limited number of related species. This is supported by the fact that most of the host records determined in this study have been recorded elsewhere. For example C. angustula is reported as a parasite of Ancistrocerus trifasciatus, Symmorphus bifasciatus and S. debilitatus in Germany (Lith, 1958; Wick1, 2001; Steffan-Dewenter \& Leschke, 2003). In addition, S. connexus is reported as its host in Germany (Wickl, 2001). Although this mason wasp was also recorded in our study it is a very rare species in Estonia where it has no importance as a host of $C$. angustula. Specialization on a limited number of closely related species occurs in $C$. iris, which is known to be a parasite of Symmorphus murarius in Germany (Alfken, 1915) and S. crassicornis in France (Buysson, 1891-1896) but was bred mostly from the nests of $S$. allobrogus in our study. Although we have no data on the abundance of these three species of Symmorphus in European countries it is likely that this cuckoo wasp selects different species of this genus as hosts depending on their availability.

Several published host-parasite relationships were not confirmed by this study despite both the host and parasite species being recorded in the trap-nests. Strikingly, this included host species that were frequently recorded in trap nests like Ancistrocerus antilope, which is known to be a host of C. longula and C. pseudobrevitarsis (Brechtel, 1986; Schmid-Egger et al., 1995); Symmorphus bifasciatus, which is recorded as a host of C. solida (Wickl, 2001); and Trypoxylon figulus, which is recorded as a host of $C$. angustula and C. fulgida (Linsenmaier, 1959; du Buysson, 1891-1896). We cannot exclude the possibility that these host-parasite relationships were not found due to different host preferences in different regions or just due to chance. However, it is also likely that the earlier host-parasite records are erroneous as they were based on inappropriate methods that did not take into account the possibility of nest usurpation (more than one potential host species in a nest).

C. ignita is known to be a parasite of numerous cavity nesting wasps and bees, making it one of the least specialized cuckoo wasps (Tormos et al., 2007). Among the hosts of this cuckoo wasp we recorded the following species in trap-nests (source identifying a species as a host of C. ignita is given in parentheses): Ancistrocerus antilope (Gathmann \& Tcharntke, 1999), A. parietinus (Gathmann \& Tcharntke, 1999), A parietum (Morgan, 1984), A. trifasciatus (Petit, 1987), Gymnomerus laevipes (Benno, 1957), Osmia bicornis (Schneider, 1991), Symmorphus bifasciatus (Wagner, 1938), S. murarius (Trautmann \& Trautmann, 1919) and Trypoxylon figulus (Coudrain et al., 2013). Although $C$. ignita is not rare in Estonia, we did not record it in trap-nests, which could be explained by a narrower host selection of this cuckoo wasp. Evidently, species of the $C$. ignita species group were not identified in some of the above studies, and some species were not split from $C$. ignita at the time of the earlier studies. Therefore, unless it is known that $C$. ignita sensu stricto was the parasite such host records are for C. ignita in the wide sense (sensu lato).

Our study revealed that cuckoo wasps have far narrower host preferences than indicated in the literature. Their niches overlap minimally, enabling high species diversity to persist without species competing intensely for hosts. At the same time, narrow specialization places species at a higher risk of extinction, due to their high dependency on the existence of a particular host species.

ACKNOWLEDGEMENTS. The authors would like to express their gratitude to T. Tammaru and A. Kaasik for help with the statistical analysis and to J. Davison for editing the English. We would also like to thank the two anonymous reviewers for their useful comments and suggestions for improving this manuscript. This study was financed by the Estonian Ministry of Education and Research (target-financed project SF0180122s08 and institutional research funding grant no IUT20-33), the Estonian Science Foundation (grants no. 7558 and 9174) and the European Union 
through the European Regional Development Fund (Center of Excellence FIBIR).

\section{REFERENCES}

Abeille de Perrein E. 1879: Synopsis critique et sinonymique des Chrysides de France. - Ann. Soc. Linn. Lyon 26: 1-108.

AlfKen J. 1915: Verzeichnis der Goldwespen (Chrysiden) Nordwestdeutschlands. - Abh. Nat. Ver. Bremen 23: 291-295.

Alves-dos-Santos I. 2003: Trap-nesting bees and wasps on the university campus in São Paulo, Southeastern Brazil (Hymenoptera: Aculeata). - J. Kans. Entomol. Soc. 76: 328-334.

Ashmead W.H. 1894: The habits of the aculeate Hymenoptera. Psyche 7: 75-79.

Asís J.D., Gayubo S.F. \& Tormos J. 1991: Notes on the natural history of Stizus perrisii ibericus Beaumont (Hymenoptera: Sphecidae). - J. Nat. Hist. 25: 1331-1337.

BALTHASAR V. 1942: [Further contribution to the knowledge of Hymenoptera of eastern Moravia.] Opuscula Hymenopterologica III. — Sb. Př́r. Klubu Brně 24: 1-8 [in Czech].

Balthasar V. 1943: [Hymenopterological studies.] Opuscula Hymenopterologica IV. — Entomol. Listy 6: 33-51 [in Czech].

BenNo P. 1950: De Nederlanse Goudwespen en haar verspreiding (Hym. Chrysididae, Cleptidae). - Publties Natuurh. Genoot. Limburg 3: 9-48.

BEnNo P. 1957: Aantekeningen bij de Rubicole Aculeaten-Fauna in Nederland (Hymenoptera: Vespidae, Sphecidae, Apidae, Chrysididae). - Entomol. Ber. 17: 143-146.

Berland L. \& Bernard F. 1938: Hymenoptères vespiformes. III (Cleptidae, Chrysidae, Trigonalidae). - Faune de France 34: $1-145$.

Boesi R., Polidori C., Tormos J., Bevacqua S., Asis J.-D. \& ANDRIETTI F. 2005: Trap-nesting Ancistrocerus sikhmensis (Hymenoptera: Eumenidae) in Nepal: nest structure and associates (Hymenoptera: Chrysididae; Acarina: Saproglyphidae). — Fla Entomol. 88: 135-140.

Brechtel F. 1986: Die Stechimmenfauna des Bienwaldes und seiner Randbereiche (Südpfalz) unter besonderer Berücksichtigung der Ökologie kunstnestbewohnender Arten. - Pollichia 9: $1-284$.

Budrienè A., Budrys E. \& Nevronytė Ž. 2004: Solitary Hymenoptera Aculeata inhabiting trap-nests in Lithuania: nesting cavity choice and niche overlap. - Latv. Entomol. 41: 19-31.

Budrys E., Ureta J., Briliūté A., Cetkovic A., Heinrich S., Kroel-Dulay G., Moora M., Potts S.G., Rortais A., Suödin E., Szentgyörgyi H., Torres I., Vighi M., Westphal C. \& BUdRIENE A. 2010: Cavity-nesting Hymenoptera across Europe: a study in ALARM project field site network sites using small trap-nests on trees and buildings. In Settele J., Penev L., Georgiev T., Grabaum R., Grobelnik V., Hammen V., Klotz S. \& Kotarac M. (eds): Atlas of Biodiversity Risk. Pensoft, Sofia \& Moscow, pp. 12-13.

Buysson R. DU 1891-1896: Les Chrysides. In André E. (ed.): Species des Hyménoptères d'Europe et d'Algerie. Vol. 6. V ve Dubosclard, Paris, I-XII + 13-758 +64 unnumbered pages + 32 pls. (1891) 1-88, (1892) 89-208, (1893) 209-272, (1894) 273-400, (1895) 401-624, (1896) 625-756 + 1*_22*, (18911896) 64 unnumbered pages +32 pls.

COOPER K.W. 1953: Biology of Eumenine wasps I. The ecology, predation, nesting and competition of Ancistrocerus antilope (Panzer). - Trans. Am. Entomol. Soc. 79: 13-35.

Coudrain V., Herzog F. \& Entling M.H. 2013: Effects of habitat fragmentation on abundance, larval food and parasitism of a spider-hunting wasp. — PLOS ONE 8: e59286.
Černá K., Zemenová M., MacháčKová L., Kolínová Z. \& StraKA J. 2013: Neighbourhood society: Nesting dynamics, usurpations and social behaviour in solitary bees. - PLOS ONE 8: e73806.

Doronin M. 1996: The hosts of some cuckoo wasps (Hymenoptera, Chrysididae) in Latvia. - Latv. Entomol. 35: 17-19.

Ebeling A., Klein A.-M., Weisser W.W. \& Tscharntke T. 2012: Multitrophic effects of experimental changes in plant diversity on cavity-nesting bees, wasps, and their parasitoids. - Oecologia 169: 453-465.

EnsLIN E. 1933: Die Bewohner der Brombeerstengel. — Entomol. Jb. 42: 134-148.

Gathmann A. \& TscharntKe T. 1999: Landschafts-Bewertung mit Bienen und Wespen in Nisthilfen: Artenspektrum, Interaktionen und Bestimmungsschlüssel. - Natursch. Lanschaftspfl. Baden-Württemberg 73: 277-305.

Gayubo S.F., Torres F. \& Mingo E. 1987: Efecto de la presión urbana sobre abejas y avispas (Hymenoptera, Aculeata) en Salamanca. II. Mutillidae y Chrysididae. — Graellsia 43: 193-204.

Habermannová J., Bogusch P. \& Straka J. 2013: Flexible host choice and common host switches in the evolution of generalist and specialist cuckoo bees (Anthophila: Sphecodes). — PLoS ONE 8: e64537.

HeInRICH J. 1964: Beitrag zur Hymenopteren-fauna des westlichen Unterfranken 1. Teil. — Nachr. Naturw. Mus. Aschaffenb. 71: 1-28.

HerRmann M. 1996: Beitrag zur Klärung der Wirtsfrage von Chrysis graelsii. - Bembix 7: 11-13.

Kimsey L. \& Bohart R. 1991: The Chrysidid Wasps of the World. Oxford Press, New York, 652 pp.

Klein A.-M., Steffan-Dewenter I. \& Buchori D. 2002: Effects of land-use intensity in tropical agroforestry systems on coffee flower-visiting and trap-nesting bees and wasps. - Conserv. Biol. 16: 1003-1014.

Krombein K.V. 1967: Trap-Nesting Wasps and Bees: Life Histories, Nests, and Associates. Smithsonian Press, Washington, D.C., 570 pp.

Kunz P.X. 1994: Die Goldwespen (Chrysididae) Baden-Württembergs. - Beih. Veröff. Natursch. Landespfl. Baden-Württemberg 77: 1-188.

Linnaeus C. 1758: Systema Naturae per Regna tria Naturae, secundum Classes, Ordines, Genera, Species, cum characteribus, differentiis, synonymis, locis. Editio Decima, Refurmata, Tomus I. Laurentii Salvii, Holmiae, 824 pp.

LinsenMaIER W. 1959: Revision der Familie Chrysididae (Hymenoptera). - Mitt. Schweiz. Entomol. Ges. 32: 1-232.

LinsenMaier W. 1997: Die Goldwespen der Schweiz. - Veroff. Natur-Mus. Luzer 9: 1-140.

Lith J.P. van 1958: [Remarks on Chrysididae (3)]. — Entomol. Ber. 18: 231-232 [in Dutch].

Matsumoto K. \& Makino S. 2011: Monitoring of tube-nesting bees and wasps with bamboo tube nest traps of different types in two types of forests in temperate Japan. - Entomol. Sci. 14: 154-161.

MedLeR J. 1964: Parasitism of Eumeninae by cuckoo wasps in trap-nests in Wisconsin. - Proc. Entomol. Soc. Wash. 66: 209-215.

Morgan D. 1984: Cuckoo-Wasps (Hymenoptera, Chrysididae). Handbooks for the Identification of British Insects. Vol. 6. Royal Entomological Society of London, London, pp. 1-37.

Petit J. 1987: Notes faunistiques et éthologiques sur les Chrysides de la Belgique et des régions limitrophes (Hymenoptera: Chrysididae). 4. Sur quelques espèces et sous espèces de groupe ignita. — Lambillionea 87: 29-35. 
SAURE C. 1998: Beobachtungen und Anmerkungen zur Wirtsbindung einiger Goldwespenarten im nordostdeutschen Raum (Hymenoptera: Chrysididae: Chrysidinae). — Bembix 10: 15-18.

Schmid-Egger C., Risch S. \& Niehuis O. 1995: Die Wildbienen und Wespen in Rheinland-Pfalz (Hymenoptera, Aculeata). Verbreitung, Ökologie und Gefährdungssituation. - Fauna Flora Rheinland-Pfalz 16: 1-292.

SCHNEIDER N. 1991: Contribution à la connaissance des Arthropodes rubicoles du Grand-Duché de Luxembourg. - Bull. Soc. Natur. Luxembourg. 92: 85-119.

SCHNEIDER N. 1997: Inventaire général et atlas provisoire des Euménides du Luxembourg (Hymenoptera, Aculeata). — Bull. Soc. Natur. Luxembourg. 98: 151-168.

Smissen J. v. D. 2001: Die Wildbienen und Wespen SchleswigHolsteins - Rote Liste. - Landes. Natur Umwelt Landes Schleswig-Holstein 1: 1-138.

Smissen J. v. D. 2010: Schlüssel zur Determination der Goldwespen der engeren ignita-Gruppe (Hymenoptera Aculeata: Chrysididae). - Verh. Ver. Naturw. Heimatforsch. Hamburg 43: 4-184.

Sмiтн F. 1858: Tribe III. Diploptera. Fam. 1. Eumenidae. In: Catalogue of British Fossorial Hymenoptera, Formicidae, and Vespidae in the Collection of the British Museum. British Museum (Natural History), London, pp. 196-211.

Soon V. \& SAarma U. 2011: Mitochondrial phylogeny of the Chrysis ignita (Hymenoptera: Chrysididae) species group based on simultaneous Bayesian alignment and phylogeny reconstruction. - Mol. Phylogen. Evol. 60: 13-20.

Soon V., Budrys E., Orlovskytè S., PaukKunen J., Ødegaard F., Ljubomirov T. \& SaArma U. 2014: Testing the validity of Northern European species in the Chrysis ignita species group (Hymenoptera: Chrysididae) with DNA Barcoding. — Zootaxa 3786: $301-330$.
StefFan-DeWenter I. \& LeschKe K. 2003: Effects of habitat management on vegetation and above-ground nesting bees and wasps of orchard meadows in Central Europe. - Biodivers. Conserv. 12: 1953-1968.

Tormos J., Asís J., Gayubo S. \& Mingo E. 1996: Description of the mature larvae of Chrysis gracillima and Omalus biaccinctus and new data on the biology of Trichrysis cyanea (Hymenoptera: Chrysididae). — Fla Entomol. 79: 56-63.

Tormos J., Asís J.D., Polidori C. \& Boesi R. 2007: Host association in Chrysis fulgida L. and description of its prepupa (Hymenoptera: Chrysididae). — J. Entomol. Sci. 42: 193-199.

Tormos J., Asís J.D., Beneitez A. \& GaYubo S.F. 2009: Description of the mature larva of the sand wasp Bembix bidentata and its parasitoids (Hymenoptera: Crabronidae, Chrysididae, Mutillidae). - Fla Entomol. 92: 43-53.

Trautmann G. \& Trautmann W. 1919: Die Goldwespenfauna Frankens. - Z. Wissensch. Insektenbiol. 15: 30-36.

Tscharntke T., Gathmann A. \& Steffan-Dewenter I. 1998: Bioindication using trap-nesting bees and wasps and their natural enemies: community structure and interactions. - J. Appl. Ecol. 35: 708-719.

WAGNER A.C.W. 1938: Die Stechimmen (Aculeaten) und Goldwespen (Chrysididaen s. 1.) des westlichen Norddeutschland. - Verh. Vereins Naturwissensch. Heimatforsch. Hamburg 26: 94-153.

WICKL K. 2001: Goldwespen der Oberpfalz (Hymenoptera: Chrysididae). - Galathea 17: 57-72.

WIESNER T. 2006: Beitrag zur Hautflüglerfauna von Branderburg - Neu- und Wiederfunde Aculeater Hymenopteren (Hymenoptera: Chrysisidae, Vespidae, Pompilidae, Crabronidae, Tiphiidae, Apidae). - Märkische Entomol. Nachr. 8: 233-242.

Received May 28, 2014; revised and accepted September 25, 2014 Prepublished online October 20, 2014 